\title{
Archivos de Zootecnia. Editorial Report 2015
}

Nogales Baena, S. 1,2@; Arando Arbulu, A. ${ }^{2}$; Navas González, F.J. ${ }^{2}$; Barona Hernández, L. '; Delgado Bermejo, J.V. 1,2; López de Bustamante, M.C. ${ }^{1}$ and Gómez Castro, A.G.'

'Editorial Office of Archivos de Zootecnia. Animal Production Department. Faculty of Veterinary Sciences. University of Córdoba. Rabanales University Campus. Córdoba. Spain.

${ }^{2}$ Genetics Department. Faculty of Veterinary Sciences. University of Córdoba. Rabanales University Campus. Córdoba. Spain.

\section{ADDITIONAL KEYWORDS}

Scientific journals.

Scientific manuscripts.

Editorial activity.

Zootechny.

Animal Production.

\section{SUMMARY}

The editorial process of Archivos de Zootecnia during 2015 is reported below. A total of 345 manuscripts coming from 24 countries, mainly from Brazil (almost 70\%), were received. Consequently, the most frequently used language in the manuscripts was Portuguese, followed by Spanish and English. 71 works were published in 2015: 54 articles, 13 short notes and 4 reviews. Published writings came from 15 countries. The two main topics the articles were about were Feeding and food $(n=36,40 \%)$ and Breeding and genetics $(n=19,21.1 \%)$; while the most frequent species the works dealt with was cattle $(n=24,26.67 \%)$. Editorial times between the reception and publication of the manuscripts have comparatively improved according to the results showed in previous years' reports.

\section{Archivos de Zootecnia. Informe Editorial 2015}

\section{RESUMEN}

\section{Palabras ClaVe adicionales}

Revistas cientificas.

Trabajos científicos.

Actividad editorial.

Zootecnia.

Producción Animal.

\section{INFORMACIÓN}

Cronología del artículo.

Recibido/Received: 29.02.2016

Aceptado/Accepted: 16.03.2016

On-line: 16.03 .2016

Correspondencia a los autores/Contact e-mail:

seio21@hotmail.com

\section{INTRODUCTION}

First of all, we would like to thank all of our reviewers for their work in 2015. During the 2015 year cycle the changes started in the previous year continued. On the one hand, efforts have been made in order to continue decreasing the current editorial times. On the other hand, the editorial board of the journal has been increased to include language editorial reviewers, which will be in charge of the revision of the manuscripts before their publication. This will bolster the best possible use of the different languages the works may be published in, and which are allowed to be used by the editorial board of the journal, providing the documents with a greater quality. The platform change that has been carried out in order to start using Open Journal Systems (OJS) has significantly delayed publishing, but the management board of the journal is working in order to make such change easier and to speed up the whole process as a mean to update and make the different journal publishing tasks easier. Such events will simultaneously mean changes on the publishing regulations of the journal, as well as on the idiosyncrasies of the internal work.

\section{SUBMISSIONS}

During 2015, a total of 345 manuscripts were received, with 265 classified as articles, 21 as short communications and 57 were reviews. The quantity of manuscripts submitted as original articles, short communications and reviews has increased when compared to the results from the previous year (Nogales Baena, Arando Arbulu, Delgado Bermejo, López de Bustamante y Gómez Castro, 2015). Manuscript numbers are continuously increasing, and have almost reached 


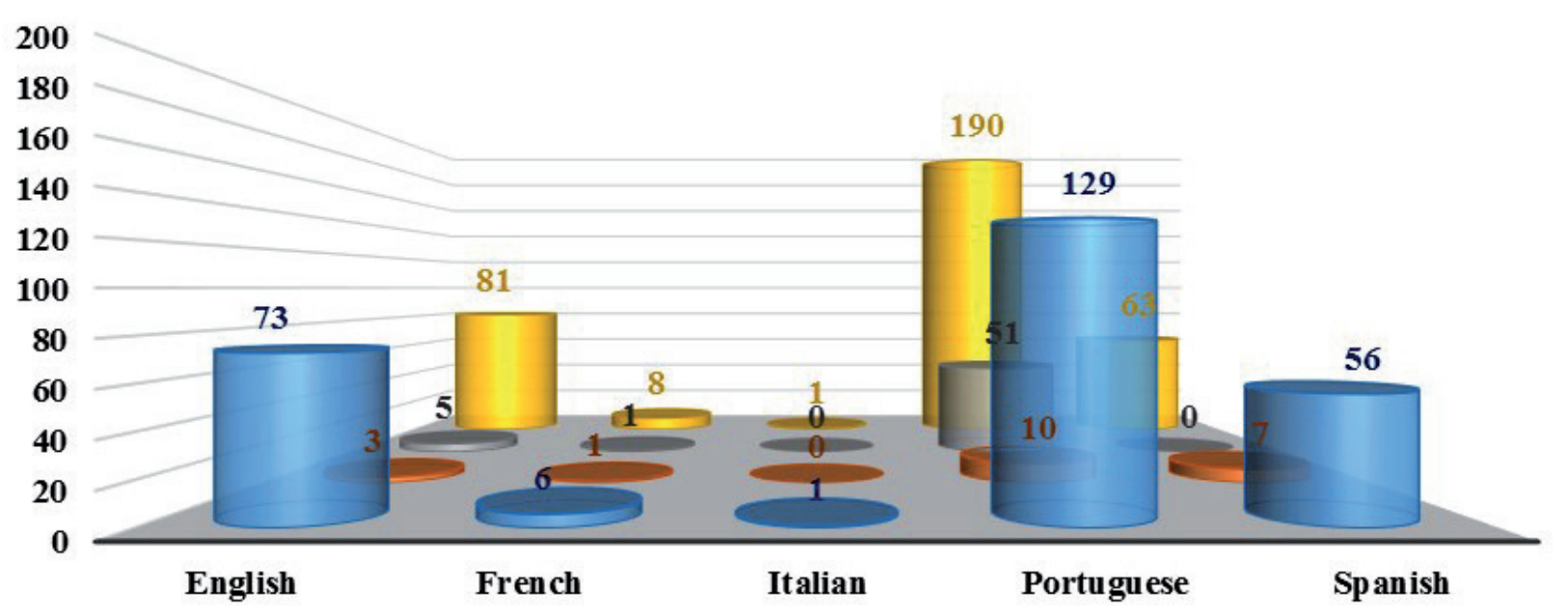

Received articles $\square$ Received short notes $\quad \square$ Received reviews $\square$ Received papers

Figure 1. Language used in the manuscripts received during 2015 (Idioma empleado en los manuscritos recibidos durante 2015).

Table I. Origin (\%) of the authors of manuscripts received and published during 2015 (Origen (\%) de los autores de los manuscritos recibidos y publicados durante 2015).

\begin{tabular}{|c|c|c|c|c|c|c|c|c|}
\hline \multirow[b]{2}{*}{ Country } & \multicolumn{4}{|c|}{ Received } & \multicolumn{4}{|c|}{ Published } \\
\hline & A & SN & $\mathrm{R}$ & $\mathrm{P}$ & A & $\mathrm{SN}$ & $\mathrm{R}$ & $P$ \\
\hline Algeria & 2.3 & - & - & 1.8 & 3.2 & - & - & 2.5 \\
\hline Argentina & 3.1 & - & - & 2.4 & 3.2 & - & - & 2.5 \\
\hline Benin & 0.7 & - & 2.0 & 0.8 & - & - & - & - \\
\hline Brazil & 68.0 & 70.0 & 96.9 & 72.2 & 60.7 & 48.3 & 94.4 & 60.3 \\
\hline Chile & 1.3 & 8.3 & - & 1.6 & 0.7 & - & - & 0.6 \\
\hline Colombia & 2.7 & 4.2 & 1.2 & 2.6 & 8.4 & 8.3 & - & 8.0 \\
\hline Croatia & 0.5 & - & - & 0.4 & - & - & - & - \\
\hline Cuba & 1.8 & - & - & 1.4 & - & 10.0 & - & 1.7 \\
\hline Ecuador & 2.0 & 5.0 & - & 1.9 & 0.7 & - & - & 0.6 \\
\hline Slovakia & 0.4 & - & - & 0.3 & 1.8 & - & - & 1.4 \\
\hline Spain & 2.3 & 5.8 & - & 2.2 & 7.0 & 6.7 & 5.6 & 6.9 \\
\hline Guatemala & 0.3 & - & - & 0.2 & - & - & - & - \\
\hline Indonesia & 0.3 & - & - & 0.2 & - & - & - & - \\
\hline Iran & 0.1 & - & - & 0.1 & 2.1 & - & - & 1.7 \\
\hline Italy & 0.6 & - & - & 0.5 & - & - & - & - \\
\hline Mexico & 4.8 & - & - & 3.8 & 2.8 & 5.0 & - & 3.0 \\
\hline Nigeria & 7.2 & - & - & 5.7 & 5.6 & 16.7 & - & 7.2 \\
\hline Peru & 0.4 & - & - & 0.3 & - & 5.0 & - & 0.8 \\
\hline Portugal & 1.1 & 4.2 & - & 1.1 & 1.1 & - & - & 0.8 \\
\hline Senegal & 0.3 & - & - & 0.2 & - & - & - & - \\
\hline Syria & 0.2 & - & - & 0.2 & - & - & - & - \\
\hline Tunisia & - & 2.5 & - & 0.2 & - & - & - & - \\
\hline Venezuela & - & - & - & - & 2.8 & - & - & 2.2 \\
\hline
\end{tabular}

$A=$ Articles $S N=$ Short notes; $R=$ Reviews; $P=$ Papers.

the results obtained in 2012 (Gómez Castro, López de Bustamante, Perea Muñoz y Arcos Castejón, 2013).The manuscripts were received in five different languages, i.e., Portuguese, Spanish, English, French and Italian. Acceptance rates were not equivalent for all languages, nor for authors' countries. Portuguese was used in the $55.39 \%$ of the documents, and was the most frequently used language. Comparing this fact to the origin of the authors, the results showed most of them were from countries where Portuguese is the official language. English was the second language (23.62\%), followed by Spanish $(18.37 \%)$. This results contrast the figures from 2014 (Nogales Baena et al., 2015), when the Spanish language reached the second position pushing English to the third position. The journal continues to make efforts so as to help improve papers with high scientific quality that are submitted from countries in which cultural and organizational difficulties may exist. This effort allows these submissions to reach a standard that is more consistent and matches the scientific community's standards. Submitted manuscripts have been classified according to their original language in figure 1.

When assessing the author's origin, Brazilians were the most frequent senders, but their number decreased when compared to the results showed by the previous report (Nogales Baena et al., 2015). The authors' origin of the rest of the papers was unequally shared among the 22 countries related in table I. Apart from Brazil the only country which was able to reach $5 \%$ was Nigeria.

Figure 2 presents the manuscripts classified according to their topics. Of the received manuscripts, more than $40 \%$ concerned Feeding and Food with a much higher percentage than the rest of the topics. The second and third most frequent topics were Products $(9.91 \%)$ and Breeding and Genetics (9.33\%), which percentages have inversely changed in order when compared to the results obtained in 2014.

\section{PUBLISHED DOCUMENTS}

In 2015, a total of 71 research documents were published with a total of 496 edited pages as shown in figures 3 and 4 . The documents published included 54 papers, 13 short communications and 4 reviews.

This translates into a decrease of $20 \%$ in the papers published, and of almost $50 \%$ in the number of pages, which contrasts the results obtained in 2014. When thoroughly assessing the details of the obtained data, it can be ensured that although there has not been an 


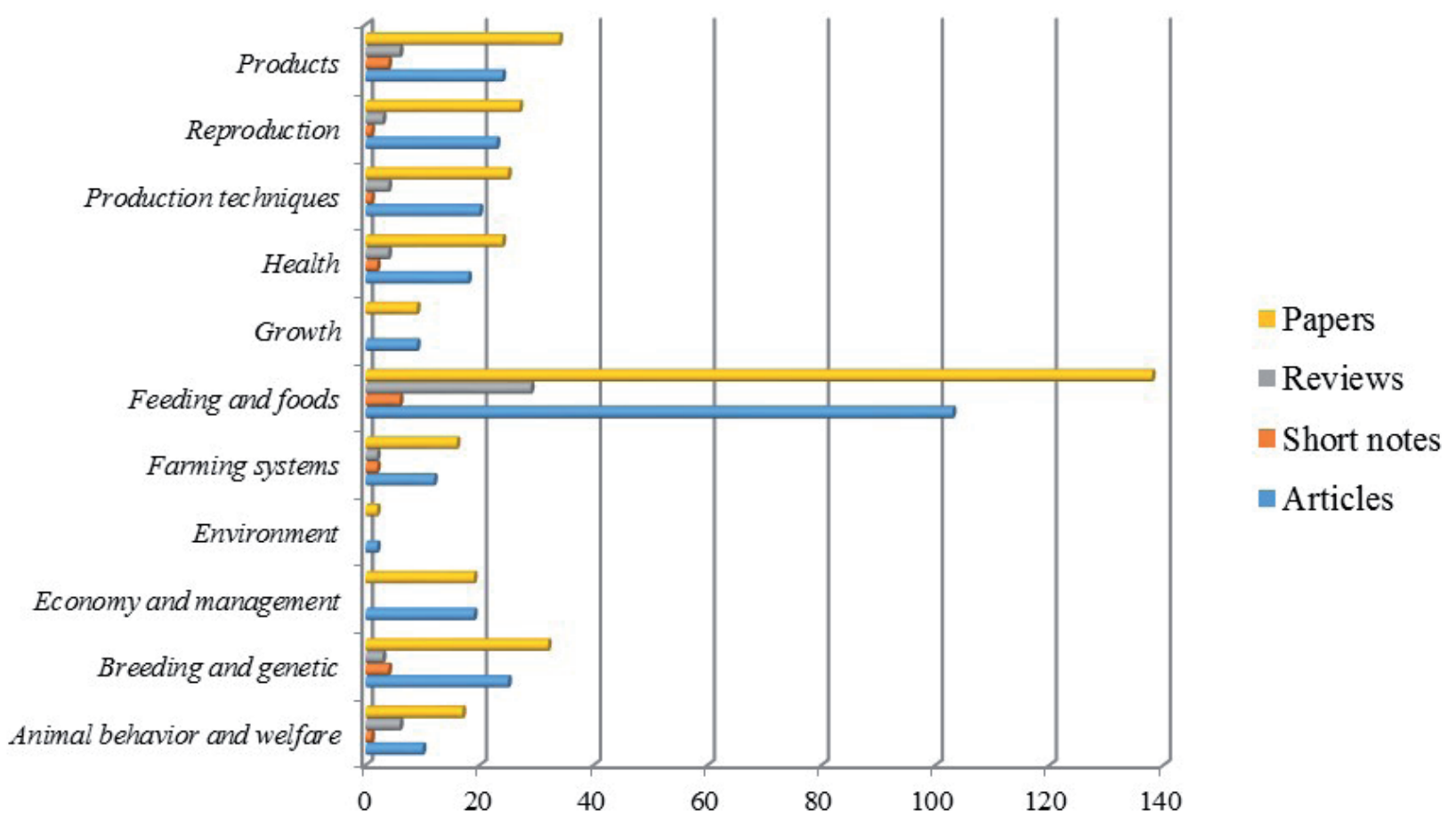

Figure 2. Topics covered in manuscripts received during 2015 (Temas tratados en los manuscritos recibidos durante 2015).

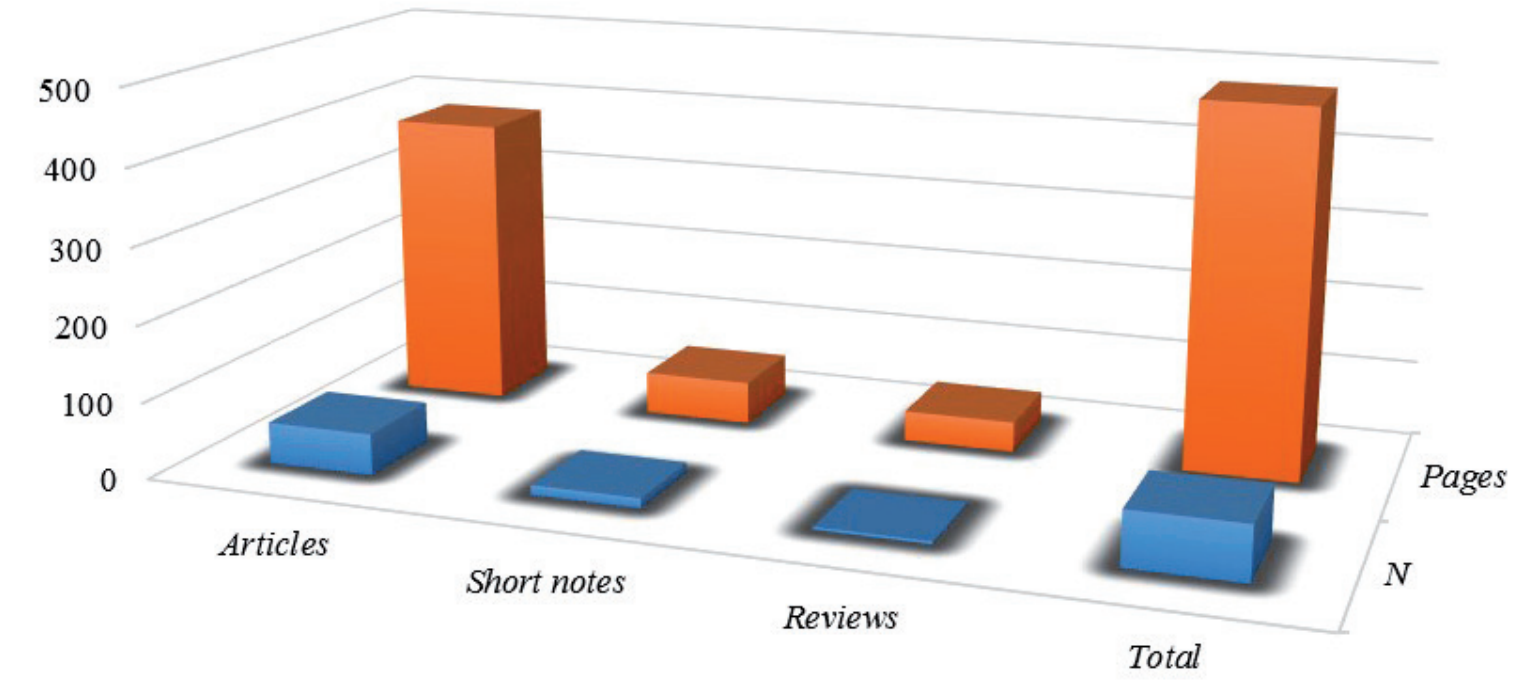

\begin{tabular}{|l|c|c|c|c|}
\cline { 2 - 5 } \multicolumn{1}{c|}{} & Articles & Short notes & Reviews & Total \\
\hline $\mathbf{N}$ & 54 & 13 & 4 & 71 \\
\hline $\mathbf{\square}$ Pages & 398 & 57 & 41 & 496 \\
\hline
\end{tabular}

Figure 3. Manuscripts published in 2015 (Manuscritos publicados durante 2015).
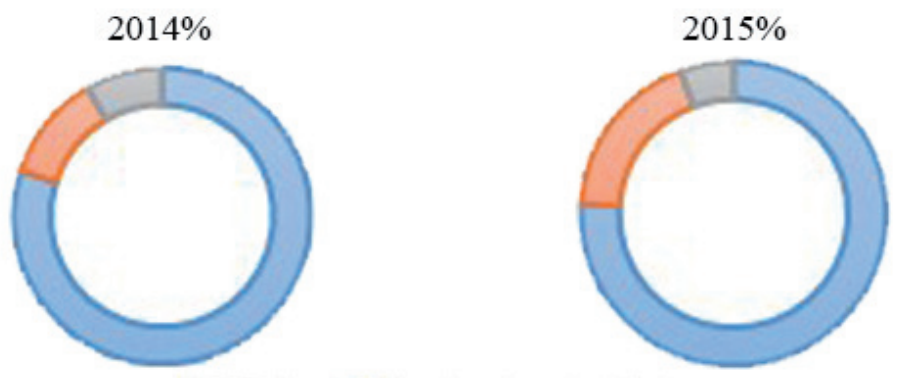

$\square$ Articles $\square$ Short notes $\square$ Reviews

Figure 4. Manuscripts published in 2014 and 2015 (Manuscritos publicados durante 2014 y 2015).

Archivos de zootecnia vol. 65, núm. 249, p. 3. 


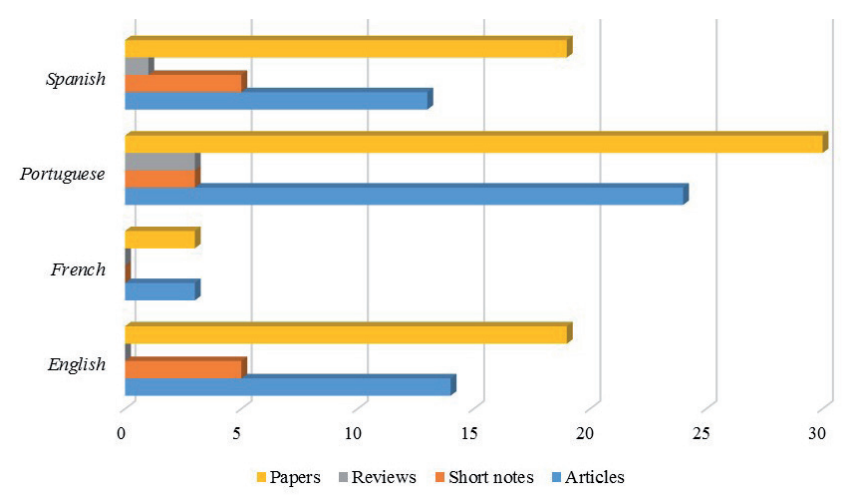

Figure 5. Language used in the manuscripts published during 2015 (Idioma empleado en los manuscritos publicados en 2015).

Table II. Topics dealt with in manuscripts received and published during 2015 (Temas tratados en los manuscritos recibidos y publicados durante 2015).

\begin{tabular}{lrrrr}
\hline & A & SN & R & P \\
\hline Animal behavior and welfare & 3 & & & 3 \\
Breeding and genetic & 9 & 3 & 1 & 13 \\
Economy and management & 4 & 1 & & 5 \\
Environment & & & & \\
Farming systems & 20 & 1 & & 1 \\
Feeding and foods & 3 & 1 & 1 & 27 \\
Growth & 7 & 1 & 1 & 4 \\
Health & 3 & & & 3 \\
Production techniques & 2 & & & 2 \\
Reproduction & 2 & & 1 & 3 \\
Products &
\end{tabular}

$A=$ Articles; $S N=$ Short notes; $R=$ Reviews; $P=$ Papers.

Table III. Species or group of species studied in manuscripts published during 2015 (Especies o grupos de especies estudiados en los manuscritos publicados durante 2015).

\begin{tabular}{lrccc}
\hline & $\mathrm{A}$ & $\mathrm{SN}$ & $\mathrm{R}$ & Total \\
Bovine & 16 & 1 & & 17 \\
Ovine & 8 & & 3 & 11 \\
Caprine & 5 & & & 5 \\
Porcine & 1 & & & 1 \\
Equine & 2 & 1 & & 3 \\
Poultry & 9 & 1 & & 10 \\
Rabbits & 1 & 1 & & 2 \\
Beekeeping & 1 & & & 1 \\
Aquaculture & 4 & & & 4 \\
Alternative species & 1 & 6 & & 7 \\
Nonspecific & 6 & 3 & 1 & 10 \\
\hline
\end{tabular}

$A=$ Articles; $S N=$ Short notes; $R=$ Reviews.

important decrease in the number of articles that were eventually published, the number of short notes and reviews has suffered a great reduction, with only 13 and 4 respectively, which relates to the number of short notes and reviews published during the previous year, which was 19 and 13 respectively (Nogales Baena et al., 2015).

Published manuscripts were written in four different languages (figure 5), with Portuguese the most frequent one $(42.25 \%)$. Contrasting the results from the previous year, the use of English increased until it reached the same level as Spanish (19 papers in each language, $26.76 \%$ out of the total of papers published). This result confirms the advance of the use of English for the works in the journal.

According to the topics (table II), published documents showed a distribution which was similar to the one showed by received documents. The most frequent dealt with Feeding and Food (38.03\%), followed by those which were about Breeding and Genetics, and Health, showing percentages of an $18.31 \%$ and a $12.68 \%$, respectively.

From a different point of view, a classification of the documents was carried out taking the species or the group of species which the research focused on into account (table III). Cattle were specifically studied in 17 documents, which makes $23.94 \%$ out of the total amount of works. Cattle were also the species which the papers more frequently dealt with, within the $A r$ chivos de Zootecnia journal as shown in the previous report. 10 documents were not species- specific, 11 focused on sheep, and 10 on poultry, which were the two most-studied species after bovines in the journal. This is identical to what happened during the previous year.

The percentage of manuscripts accepted for publication in 2014 was approximately $32 \%$. Forty-four percent from documents in English and 40\% from those in Spanish were accepted. The number of accepted documents in Portuguese decreased to $25 \%$. Nevertheless, the percentage of accepted short communications in Portuguese was the highest, $89 \%$.

\section{EDITORIAL TIMING}

Each manuscript submitted to Archivos de Zootecnia is first reviewed by the members of the Editorial Board and Advisory Council. Subsequently, the Editorial Board analyzes each submitted manuscript at its plenary session and decides whether it must be reviewed (in which case at least two, and up to four reviewers, are assigned) or rejected.

Reviewers are chosen from a repertoire of 2091 renowned international experts. During 2015, 135 referees from 14 different countries have participated in the reviewing process of the received manuscripts. The mean editorial times during 2015 are reported in table IV.

Table IV. Editorial timing during 2015 (mean \pm standard deviation) (Tiempos editoriales durante 2015; media \pm desviación típica).

\begin{tabular}{llll}
\hline & \multicolumn{1}{c}{ R-A } & \multicolumn{1}{c}{ A-P } & \multicolumn{1}{c}{ R-P } \\
\hline Articles & $223.87 \pm 108.97$ & $81.80 \pm 31.11$ & $305.67 \pm 112.16$ \\
Short notes & $196.54 \pm 100.47$ & $90.69 \pm 38.89$ & $287.23 \pm 103.34$ \\
Reviews & $132.50 \pm 3.00$ & $99.25 \pm 44.69$ & $231.75 \pm 46.51$ \\
Total & $213.72 \pm 105.98$ & $84.41 \pm 33.21$ & $298.13 \pm 108.47$ \\
\hline
\end{tabular}

$\mathrm{R}-\mathrm{A}=$ Reception-Acceptation; A-P = Acceptation-Publication; $\mathrm{R}-\mathrm{P}=$ Reception-Publication. 


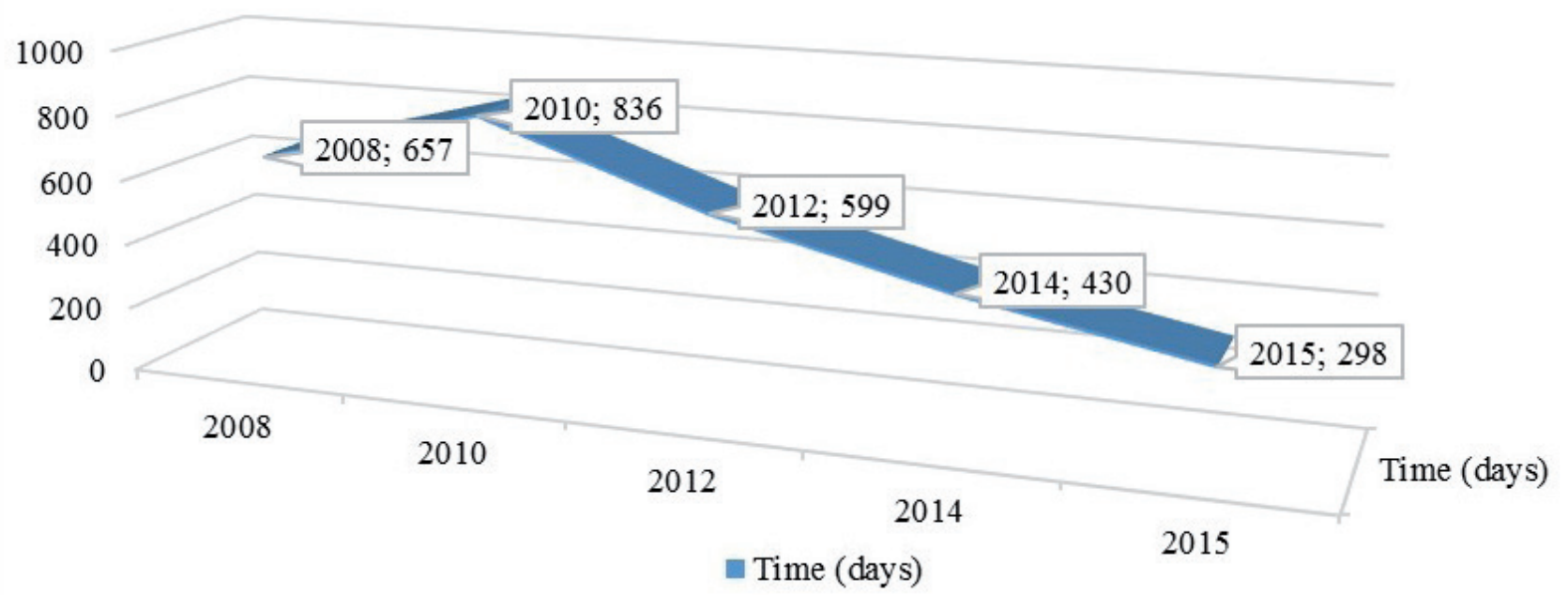

Figure 6. Editorial timing (reception-publishing) over the last years (Tiempos editoriales, recepción-publicación, durante los últimos años).

The average time between reception and acceptance was $214 \pm 106$ days, while the average time between acceptance and publication was $84 \pm 33$ days. The total days from reception to publication were $298 \pm 108$. This results can be considered to be quite positive, in contrast with the ones deduced from previous year's editorial reports (Gómez Castro, López de Bustamante, Perea Muñoz y Arcos Castejón, 2009, 2010, 2011, 2012; Gómez Castro et al., 2013; Nogales Baena et al., 2015).

The decrease in the editorial timing, already been mentioned in the previous report, has improved even more during 2015. The existing time between the reception and acceptance of the papers has had an average reduction of 80 days, which also reduced to an average of 60 days in the case of the time between the acceptance and publishing of such papers. The total day count, considering both periods; i.e., the time between the reception of a work and its publishing decreased by more than 130 days. The changes in publishing time can be observed in the chart in figure 6 . These data proves the changes implemented on working methodology were effective as had been predicted in advance.

Editorial times have significantly improved. Since 2012 Archivos de Zootecnia has only been available in electronic format. In addition, in 2014, a new team was engaged in the composition of the journal. Both changes have helped to overcome some of the problems which had increased the time for publication in previous periods.

Archivos de Zootecnia is included in a large number of directories, but the editorial committee's purpose is to increase that number in the coming years, in order to spread the journal as widely as possible. In this context, it may be noted that the website has received more than 3750000 page views, while at the end of 2011 the number of visits was 2300000 .

\section{IMPACT FACTOR}

Archivos de Zootecnia achieved an impact factor of 0.23 in the report of SCImago Journal Rank (SJR) in 2014, what means the journal is still located in the third quartile for the fifth year in a row.
Table IV and V. Impact factor evolution from 2009 until the previous periodo editorial 2014 (SCImagoLab, 2016) (Evolución del índice de impacto de 2009 hasta el pasado periodo editorial en 2014 (SCImagoLab, 2016)).

\begin{tabular}{|c|c|c|c|c|c|c|}
\hline \multirow[b]{2}{*}{ Category } & \multicolumn{6}{|c|}{$\begin{array}{l}\text { Quartile (Q1 means highest values } \\
\text { and Q4 lowest values) }\end{array}$} \\
\hline & 2009 & 2010 & 2011 & 2012 & 2013 & 2014 \\
\hline Animal Science and Zoology & Q4] & Q4 & Q3 & Q3 & Q3 & Q3 \\
\hline \multicolumn{7}{|l|}{ Indicators } \\
\hline SJR & 0.134 & 0.16 & 0.274 & 0.223 & 0.252 & 0.23 \\
\hline Total documents & 79 & 58 & 129 & 55 & 72 & 55 \\
\hline Total documents ( 3 ye & 73 & 152 & 210 & 266 & 242 & 256 \\
\hline Total references & 1385 & 1261 & 2665 & 1397 & 1584 & 1370 \\
\hline Total & 15 & 36 & 65 & 82 & 64 & 59 \\
\hline Self cites & 0 & 1 & 13 & 6 & 4 & 6 \\
\hline Citable cocuments ( 3 years) & 72 & 150 & 206 & 257 & 229 & 236 \\
\hline Cites / Document (4 years) & 0.21 & 0.24 & 0.32 & 0.4 & 0.35 & 0.28 \\
\hline Cites / Document (3 years) & 0.21 & 0.24 & 0.32 & 0.32 & 0.28 & 0.25 \\
\hline Cites / Document (2 years) & 0.21 & 0.24 & 0.32 & 0.26 & 0.27 & 0.14 \\
\hline References / Document & 17.53 & 21.74 & 20.66 & 25.4 & 22 & 24.91 \\
\hline Cited documents & 15 & 29 & 47 & 63 & 47 & 41 \\
\hline Uncited documents & 58 & 123 & 163 & 203 & 195 & 215 \\
\hline $\begin{array}{l}\% \text { International collabora- } \\
\text { tion }\end{array}$ & 7.59 & 12.07 & 10.8 & 12.73 & 5.56 & 7.27 \\
\hline
\end{tabular}

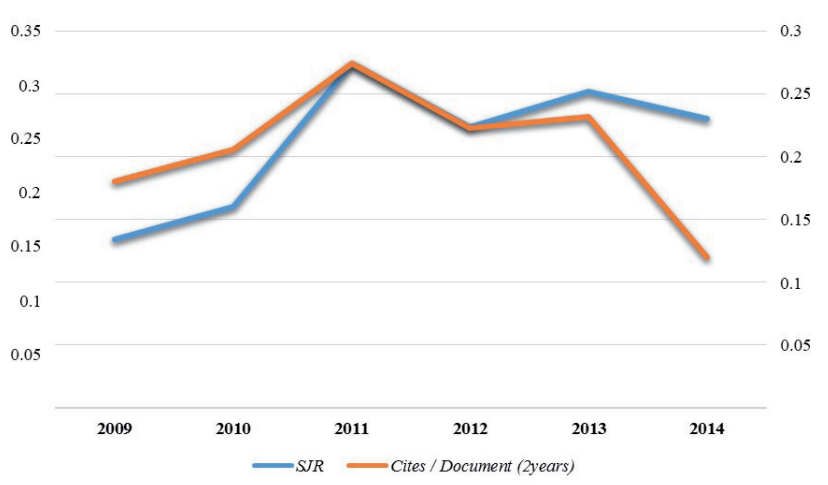

Figure 7. Impact factor evolution from 2009 until the previous periodo editorial 2014 (ScimagoLab, 2016) (Evolución del índice de impacto de 2009 hasta el pasado periodo editorial en 2014 (ScimagoLab, 2016)). 


\section{CONCLUSIONS}

The main objective of Archivos de Zootecnia is to reflect the academic activities of the world of animal production and zootechny, as well as to attract the best publications, both articles and short notes, and reviews within the fields it deals with. It also aims to attract attention to emerging fields or questions based on the focus provided by themed sections, with an international scope in order to increase the existing worldwide knowledge, as it has continued doing it since it was founded in 1952.

\section{BIBLIOGRAPHY}

Gómez Castro, A.G.; López de Bustamante, M.C.; Perea Muñoz, J. and Arcos Castejón, J. 2009. Archivos de Zootecnia. Editorial Report 2008. Arch Zootec, 58: 3-10.
Gómez Castro, A.G.; López de Bustamante, M.C.; Perea Muñoz, J. and Arcos Castejón, J. 2010. Archivos de Zootecnia. Editorial Report 2009. Arch Zootec, 59: 3-10.

Gómez Castro, A.G.; López de Bustamante, M.C.; Perea Muñoz, J. and Arcos Castejón, J. 2011. Archivos de Zootecnia. Editorial Report 2010. Arch Zootec, 60: 3-10.

Gómez Castro, A.G.; López de Bustamante, M.C.; Perea Muñoz, J. and Arcos Castejón, J. 2012. Archivos de Zootecnia. Editorial Report 2011. Arch Zootec, 61: 3-9.

Gómez Castro, A.G.; López de Bustamante, M.C.; Perea Muñoz, J. and Arcos Castejón, J. 2013. Archivos de Zootecnia. Editorial Report 2012. Arch Zootec, 62: 3-7.

Nogales Baena, S.; Arando Arbulu, A.; Delgado Bermejo, J.V.; López de Bustamante, M.C. and Gómez Castro, A.G. 2015. Archivos de Zootecnia. Editorial Report 2014. Arch Zootec, 64: 1-4.

ScimagoLab. 2016. SClmago Journal and Country Rank. Retrieved, http: //www.scimagojr.com (19/02/2016). 